\title{
Religion and Education: the Czech Situation (Review)
}

\author{
Jitka Schlichtsová
}

"In contemporary Europe, the relationship between religion and education is a frequently debated topic. In Western European countries, such as Great Britain, Norway, and the Netherlands, it became discussed as early as in the 1960s and as the number of foreign immigrants increased, it gradually became more and more pressing. Many countries started to realize that in an ethnically and religiously pluralistic society, uniting all the inhabitants of a state on the basis of a single Christian creed is extremely difficult. Consequently, while confessional education kept its place in the school curricula, the educational space started to open itself to reflection of other religious traditions." So states Zuzana Černá in the introduction to her doctoral thesis, which was defended in 2017 at the Department of Religious Studies of the Faculty of Arts, University of Pardubice, and which has recently been published. ${ }^{1}$ She also insists that in the countries of Eastern Europe, interest in the problem only started to getting stronger in the 1990s (allowing for differences between the countries). Černá believes that the greatest rise in interest came after September 11, 2001 when the Council of Europe issued a series of recommendations related to the issue. According to Černá, it was precisely at this time that the Czech Republic realized the need to use the conclusions of Religious Studies in religious education, both at the grammar school and high school levels. ${ }^{2}$ The most pressing matter at hand, which has to be conveyed to Czech students, is the support of pluralistic society, respect to foreign cultures (especially the non-European ones), and prevention of future conflicts. In her monograph, Černá asks herself the following core question: "How does our cultural tradition refer to the 'otherness' of Non-European cultures?"

Černá seeks to answer the question by means of analyzing randomly selected high school textbooks of History, Geography, and Social Sciences. She identifies the paragraphs which either define the different religions of the world or emphasize religions in the context of describing both European and Non-European cultural realities and their historical and geographical dimensions. She bases her work primarily on a comparative study of cultures proposed by S. N. Balagangadhara and his team of researchers based at the University of Ghent. In his work, Balagangadhara insists that Western Religious Studies and its approach to Non-European cultures has always

1 ZuZANa ČERnÁ, Reflexe náboženství ve vzdělávání s důrazem na analýzu českých středoškolských materiáli̊, Pardubice: Univerzita Pardubice 2017, p. 14.

2 ČERnÁ, Reflexe náboženství ve vzděláváni ..., p. 15. 
been influenced by a Christian bias. Therefore, the discipline is unable to produce a true understanding of cultures outside the Euro-American Christian context and their essential difference. He also believes that another basic problem of the current Religious Studies is the idea that every culture has to have religion. According to Balagangadhara, Religious Studies thus tends to us the label "religious" for a whole range of phenomena that, in fact, are not necessarily religious at all; by this means, the discipline creates a picture which fits better to the European Christian type of thought. Černá follows up on these thoughts and applies them to the selected educational material.

The book is divided into twelve chapters. The first four, "Introduction", "Religion and education in selected EU states", "Model approaches to education about religion", and "Religion in Czech school legislation" introduce the reader to the full context of the problem. The author defines the starting points and goals of the book, reiterates the most important theses of Balagangadhara's team and summarizes the different approaches to education on religion, both in the EU and the Czech Republic. The fourth chapter is of a special interest both for Czech and foreign scholars, since it contains an overview of the General Educational Programs (Rámcové vzdělávací program), which form the basis for the Czech education, both on the grammar school and high school level. While the introduction is not very extensive and could have been expanded on, it provides enough insight into the educational system of Czech high schools for a scholar to build on.

The eight remaining chapters form a unit, which the author labelled "Analysis of the educational materials." In each chapter, she selects a specific theme that she previously identified in the textbooks and interprets it in the light of Balagangadhara's theories. The first of these themes is the abovementioned suggestion of many of the textbook's authors - that religion is a universal trait which, albeit in a slightly different form, appears in each and every human culture in history. ${ }^{3}$ Černá specifically questions the assumption that even prehistoric peoples had religion and scrutinizes its descriptions that appear in the textbooks. According to Balagangadhara, this type of interpretation is distorted by the uncritical application of Christian bias and the usage of typical terms that belong in the context of Christian theology ("God", "worship", "idolatry", etc.). Černá also mentions China as an important moment in the discussion about the universality of religion in human cultures, which introduced a possibility of a truly atheistic society into the traditional description of religion. ${ }^{4}$

In the chapter called "Characteristic features of religion", Černá selects specific terms that the Religious studies usually use to describe religion. The biggest problem in her opinion is that the textbooks treat the terms such as "religion" and "faith" as something which the reader should know intimately. According to her, this creates an impression that these terms are universal and that they represent a clearly defined, systematic concept. Again she refers to the core problem of the definition of religion

3 ČERnÁ, Reflexe náboženství ve vzdělávání..., p. 53-63.

4 ČERnÁ, Reflexe náboženství ve vzděláváni ..., p. 63-65. 
and agrees with Balagangadhara that there is no consensus on it, meaning that the Religious Studies are unable to define its core point of interest. She insists that this problem is rooted in Christian bias and in the way the description of religious phenomena draws upon the Christian concept of priesthood, ${ }^{5}$ myths and gods, ${ }^{6}$ sacred texts, ${ }^{7}$ the possible non-religious nature of traditions such as Buddhism, Daoism, and "Hinduism", ${ }^{8}$ and religious tolerance. ${ }^{9}$

Aside from the question of definitions and terms used to describe different religious traditions, the high school texts (and therefore also Černás analysis) focus on the taxonomy of the religions of the world. The author summarizes the different approaches to the classification of religious traditions and their core thoughts. Again, Černá points out the great multitude of different approaches used for creating taxonomies and she studies the frameworks used by the textbooks' authors. She highlights the inconsistencies that appear in these taxonomies and looks at the different reasons behind the placement of each tradition in its respective taxonomy. A specific sub-chapter is dedicated to the question of polytheistic, "primitive", and national religions and their relationship to "idolatry". ${ }^{10}$

The last four chapters of the monograph focus mostly on History textbooks and the last one also on Geography textbooks. Zuzana Černá describes the textbooks' tendency to divide historical religions and their specific traits into four eras: Early Christianity and Reformation; ;1 the question of religious tolerance in Europe in the 16 th-18th century; ${ }^{12}$ the Modern era with its considerable distance from religion; ${ }^{13}$ and the 20 th century. ${ }^{14}$

The last chapter, which analyzes the 20th century approaches to religion, is mostly based on Geography textbooks. Černá notes that the authors tend to divide the world into specific civilizational spheres, which are usually connected with the region's major religion. However, they are not able to provide either a precise definition of the spheres, or the criteria used to distinguish them. Černá shows the way in which the authors mention the Hindu, Buddhist, Christian, Jewish, and Islamic sphere. The majority of her book is focused on Christianity, the history of Christianity, and the influence of Christianity on the concept of religion, again based on the theories of S. N. Balagangadhara and J. De Roover; she apparently uses the fragments of the analyzed textbooks to confirm the theses of Balagangadhara's research team. However, the true strength of the book is revealed in the last chapter, where the author fully shows her mastery of Near Eastern Studies. It is specifically in the chapters dedicated to Islam and Judaism

${ }^{5}$ ČERnÁ, Reflexe náboženství ve vzdělávání..., p. 67-74.

${ }^{6}$ ČERnÁ, Reflexe náboženství ve vzdělávání..., p. 74-78.

7 ČERnÁ, Reflexe náboženství ve vzdělávání ..., p. 78-81.

${ }^{8}$ ČERná, Reflexe náboženství ve vzděláváni ..., p. 81-83.

${ }^{9}$ ČERnÁ, Reflexe náboženství ve vzdélávání ..., p. 83-89.

${ }^{10}$ ČERNÁ, Reflexe náboženství ve vzdělávání..., p. 97-101.

${ }_{11}$ ČERnÁ, Reflexe náboženství ve vzděláváni ..., p. 102-115.

12 ČERná, Reflexe náboženství ve vzděláváni ..., p. 116-121.

${ }^{13}$ ČERná, Reflexe náboženství ve vzděláváni ..., p. 122-141.

${ }^{14}$ ČERná, Reflexe náboženství ve vzdělávání ..., p. 142-170. 
where Zuzana Černás analysis reveals a deep understanding based not only on the knowledge of both the history and the current situation of the region, but also on her personal experiences with the region.

On one hand, Zuzana Černás book is a good critical analysis of the concept of religion; however on the other hand, it also has several questionable traits, which the reader should take into account. First of all, there is the problem of the textbook selection. There were apparently no specific criteria to it - it was based neither on the year of publishing, their authors' erudition, their presence on the Ministry of Education's list of approved textbooks, nor on the type of high school. Černás selection of her primary sources was based exclusively on the fact that they appeared on some school's list of recommended textbooks. However, since schools are under no obligation to make their lists of textbooks publicly available, only a minor part of them announce their recommendations (and only as a service for prospective students and their parents). Subsequently, it is impossible to say whether the books selected by Černá are actually used by a majority of high schools or not.

Based on the relevant parts of these randomly selected textbooks, Černá shows that their authors didn't always use the religious terms and concepts in a perceptive and neutral way. She concludes that the information presented in the textbooks doesn't match the current conclusions of Religious Studies research. However, she omits the fact that the books' aim is not to teach Religious Studies as such and that they were generally published long before the scholarly texts Černá bases her analyses on.

In the same way, we may question Černás criticism of the fact that most of the space in the textbooks is dedicated both to Christianity and its geographical area and that foreign cultures are mentioned only in a relationship to the European (Christian) area. We may agree with this to a certain extent; however, we have to keep in mind that this type of focus is closely related to the date of the textbooks' publication. Due to the population demographic and social situation in the times when most of these books were written, there was no specific reason to put any exceptional stress on the Non-European areas. The textbooks mostly aimed to introduce the students to their own historical and political context and to build their worldview as inhabitants of a specific geographical area of the 1990s and early 2000s. Naturally the situation has changed since then (along with the demographic composition of the Czech population) and the necessity of intercultural education has risen sharply. In this sense, Černá could have simply pointed out that it's highly recommendable to use recently published material which reflects the current situation better. Unfortunately she cannot do this, since she doesn't know how frequently these outdated textbooks are used.

Černá also points out repeatedly that the authors simply expect the pupils to have an idea of the meaning of such terms as religion, priesthood, divinity, idolatry, and paganism; the books provide no definitions. She therefore deduces the textbooks do not help the students to grasp the terms. Nevertheless, the question remains whether this is negative - in practice, this may actually be an advantage. Černá herself insists that even contemporary Religious Studies must reframe their core terms and approaches. 
Moreover, from the pedagogical point of view, the textbooks should only serve as a complementary source of education, not as an authority which would overrule the teacher's insight and erudition. In fact, the educators who teach the subject tend to be interested in the current state of knowledge in the relevant discipline and may use the textbooks in a way that helps the students develop a better understanding of the provided information, as well as critical thinking. This is especially relevant to the current world as new information is more readily available than it was in the past and scholarly research advances at a much higher pace. Consequently, no book should be considered fully up-to-date, especially in the long term.

All in all, even though the author declares in the introduction that her goal is not to correct the mistakes in the textbooks, that is effectively what the book is doing. And in the end, these mistakes are used to introduce and confirm the results of S. N. Balagangadhara's and his team's research. While Černá offers a clear and precise summary of the problems, her analysis can be considered one-sided and excessively critical. Moreover, the book doesn't even answer Černás principal question about the way our cultural tradition reflects the "otherness" of non-European cultures. The only conclusion is that a randomly selected group of older high school textbooks (which aren't even meant to teach Religious Studies) give an erroneous account not only of non-European, but also of European traditions. The author specifically emphasizes the reasons behind these errors: according to her, they lay in the very discourse of Religious Studies (the concept and term of religion, its definition, and the language and terminology we use to describe cultures and traditions) and its inability to describe religions other than Christianity. Yes, the intent to show these problems through the analysis of high school textbooks seems illustrative and the book is highly readable and well arranged. However, in the end it contains little more than the author's affirmation of S. N. Balagangadhara and his team's research project.

\section{References}

ZuZANA ČERNÁ, Reflexe náboženství ve vzdělávánís dưrazem na analýzu českých středoškolských materiálů, Pardubice: Univerzita Pardubice 2017, 198 p. 